\title{
Kobieta w wieku 59 lat z zaburzeniami lipidowymi oraz źle kontrolowanym nadciśnieniem tętniczym w godzinach wieczornych i w nocy
}

\section{A 59-year-old woman with dyslipidemia and poorly controlled hypertension in the evening at night}

\author{
Ewa Warchoł-Celińska, Marta Karcz, Joanna Obarska, Marek Kabat \\ Klinika Nadciśnienia Tętniczego Instytutu Kardiologii w Warszawie
}

\section{Streszczenie}

Przedstawiono przypadek 59-letniej kobiety z nadciśnieniem tętniczym źle kontrolowanym w godzinach wieczornych i w nocy wspótistniejącym z zaburzeniami gospodarki lipidowej oraz węglowodanowej, przerostem lewej komory serca i obturacyjnym bezdechem sennym. W prezentowanym przypadku przeanalizowano możliwość wykorzystania całodobowej rejestracji ciśnienia tętniczego w celu optymalizacji terapii nadciśnienia tętniczego przez całą dobę. W aktualnych wytycznych podkreśla się, że optymalne zmniejszenie globalnego ryzyka powikłań sercowo-naczyniowych uzyskuje się poprzez jednoczesne obniżenie ciśnienia tętniczego i stężenia cholesterolu frakcji LDL (low-density lipoprotein). W przedstawionym przypadku docelowe wartości ciśnienia tętniczego oraz docelowe stężenie cholesterolu frakcji LDL uzyskano, włączając do leczenia walsartan i rosuwastatynę.

Słowa kluczowe: nadciśnienie tętnicze, zaburzenia lipidowe, chronoterapia nadciśnienia tętniczego, ryzyko sercowo-naczyniowe

Folia Cardiologica 2017; 12, supl. B: B9-B12

\section{Opis przypadku}

W artykule opisano przypadek 59-letniej chorej, która się zgłosiła na wizytę do lekarza rodzinnego z powodu podwyższonych wartości ciśnienia tętniczego stwierdzanych w pomiarach domowych mimo stosowanego leczenia. Nadciśnienie tętnicze rozpoznano rok wcześniej i rozpoczęto leczenie indapamidem.

Obecnie w pomiarach domowych wartości ciśnienia tętniczego wahały się w granicach 138-161/85-105 mm Hg. Tydzień przed wizytą chora wykonywała pomiary w domu - średnie wartości wynosiły 146/96 mm Hg. Wartości ciśnienia tętniczego w pomiarach porannych (wykonywanych zgodnie z obowiązującymi zasadami przed przyjęciem leków i przed posiłkiem) były wyższe (149/100 mm Hg) niż wartości ciśnienia tętniczego w pomiarach w godzinach popołudniowych (136/91 mm Hg).

Rok wcześniej rozpoznano u chorej zaburzenia lipidowe leczone obecnie simwastatyną $(20 \mathrm{mg} / \mathrm{d}$.). Podobnie, przed rokiem, w badaniu polisomnograficznym stwierdzono obturacyjny bezdech senny (OSA, obstructive sleep apnea) w stopniu umiarkowanym (wskaźnik bezdechów i oddechów spłyconych - 19/h). Pulmonolog zakwalifikował pacjentkę do leczenia z użyciem dodatniego ciśnienia w drogach oddechowych (CPAP, continuous positive airway pressure), na co nie wyraziła dotychczas zgody.

Adres do korespondencji: dr n. med. Ewa Warchoł-Celińska, Klinika Nadciśnienia Tętniczego, Instytut Kardiologii w Warszawie, ul. Alpejska 42, 04-628 Warszawa, e-mail: ewarchol@ikard.pl 


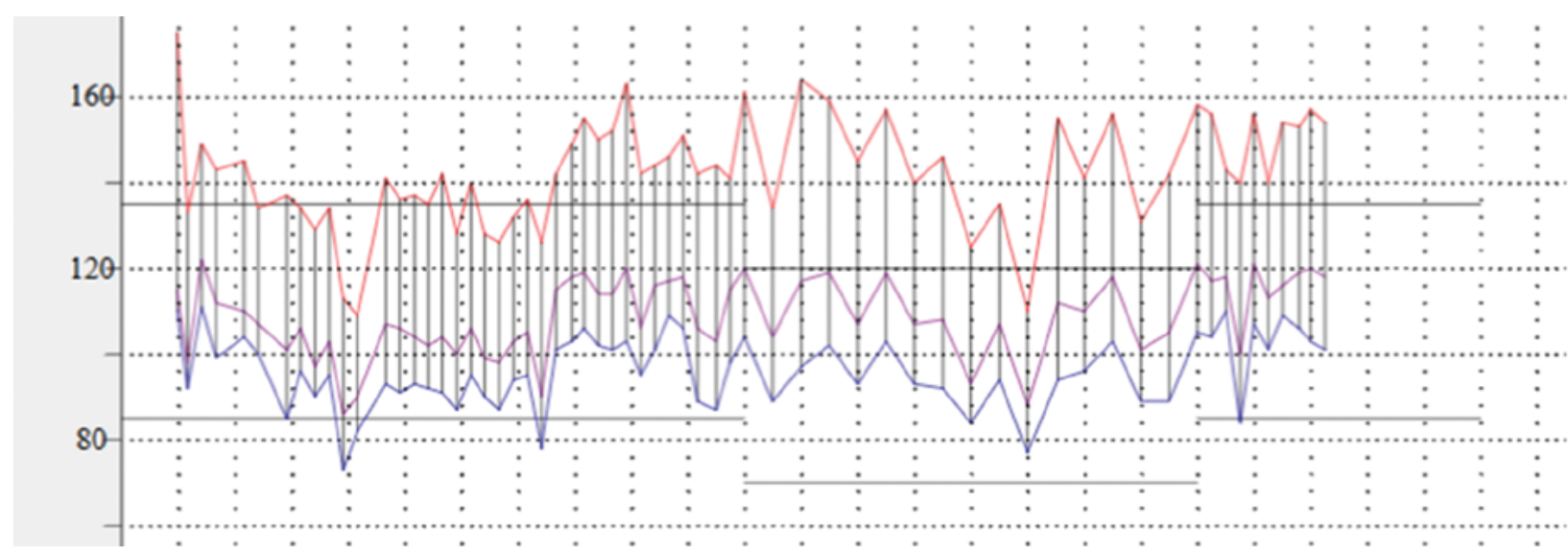

Rycina 1. Całodobowa rejestracja ciśnienia tętniczego - średnie wartości ciśnienia tętniczego z całej doby 142/96 mm Hg (prawidłowe < 130/80 mm Hg), z dnia 142/97 mm Hg (prawidłowe < 135/85 mm Hg) i z nocy 144/94 mm Hg (prawidłowe < 120/70 mm Hg)

Ostatnia miesiączka u chorej wystąpiła w 48. roku życia. Pacjentka nie stosowała hormonalnej terapii zastępczej. Ojciec chorej cierpi na nadciśnienie tętnicze. W 62. roku życia wystąpił u niego udar mózgu. Chora jest urzędniczką, prowadzi siedzący tryb życia. Obecnie nie pali i wcześniej nie paliła tytoniu, alkohol spożywa okazjonalnie -1-2 razy w miesiącu wypija 1-2 kieliszki wina.

W badaniu przedmiotowym stwierdzono otyłość o charakterze brzusznym (masa ciała - $85 \mathrm{~kg}$, wzrost $164 \mathrm{~cm}$, wskaźnik masy ciała [BMI, body mass index] - 31,6 kg/ $\mathrm{m}^{2}$, obwód szyi $-43 \mathrm{~cm}$, obwód pasa $-94 \mathrm{~cm}$ ). Tętno było miarowe o częstotliwości 74/min, średnia wartość ciśnienia tętniczego z trzech pomiarów klinicznych wykonanych w pozycji siedzącej wynosiła 142/82 $\mathrm{mm} \mathrm{Hg}$, natomiast po 1 i 3 minutach pionizacji, odpowiednio, 143/82 mm $\mathrm{Hg}$ i 142/83 mm Hg.

W zapisie elektrokardiograficznym (EKG) rytm zatokowy okazał się miarowy i wynosił 72/min, oś pośrednia; stwierdzono cechy przerostu lewej komory. Ze względu na rozbieżności między stopniem kontroli ciśnienia tętniczego w pomiarach klinicznych i pomiarach domowych lekarz zalecił chorej ponowną wizytę lekarską za 4 tygodnie po wykonaniu całodobowej rejestracji ciśnienia tętniczego (ABPM, ambulatory blood pressure monitoring). Zlecono również wykonanie badań podstawowych.

Po 4 tygodniach chora zgłosiła się na kolejną wizytę lekarską. Średnia wartość ciśnienia tętniczego z trzech pomiarów klinicznych wykonanych w pozycji siedzącej wynosiła 143/83 mm Hg. W ABPM średnie wartości z dnia wynosiły 142/97 mm Hg (prawidłowe < 135/85 mm Hg), a z nocy 144/94 mm Hg (prawidłowe < 120/70 mm Hg) (ryc. 1). Analiza profilu ciśnienia tętniczego ujawniła niekorzystne rokowniczo zjawiska - podwyższone ciśnienie tętnicze w nocy, brak spadku ciśnienia tętniczego w nocy i istotnie podwyższone wartości ciśnienia tętniczego w go-
Tabela 1. Wyniki badań laboratoryjnych

\begin{tabular}{|c|c|}
\hline Oznaczenie (jednostka) & Wynik \\
\hline Stężenie hemoglobiny [g/dl] & 15,2 \\
\hline Wartość hematokrytu (\%) & 43 \\
\hline Stężenie sodu [mmol/l] & 141 \\
\hline Stężenie potasu [mmol/l] & 4,0 \\
\hline Stężenie glukozy na czczo [mmol/l] & 6,1 \\
\hline Stężenie kreatyniny [ $\mu \mathrm{mol} / \mathrm{l}]$ & 78 \\
\hline $\begin{array}{l}\text { Przesączanie kłębuszkowe } \\
{\left[\mathrm{ml} / \mathrm{min} / 1,73 \mathrm{~m}^{2}\right]}\end{array}$ & $\geq 90$ \\
\hline Stężenie kwasu moczowego [ $\mu \mathrm{mol} / \mathrm{l}]$ & 306 \\
\hline $\begin{array}{l}\text { Stężenie cholesterolu całkowitego } \\
{[\mathrm{mmol} / \mathrm{l}]}\end{array}$ & 5,8 \\
\hline $\begin{array}{l}\text { Stężenie cholesterolu } \\
\text { frakcji LDL [mmol/l] }\end{array}$ & 3,8 \\
\hline $\begin{array}{l}\text { Stężenie cholesterolu } \\
\text { frakcji HDL [mmol/l] }\end{array}$ & 1,4 \\
\hline Stężenie triglicerydów [mmol/l] & 1,8 \\
\hline Stężenie ASpaT [j./l] & 26 \\
\hline Stężenie ALAT [j./l] & 23 \\
\hline Badanie ogólne moczu & Prawidłowy \\
\hline
\end{tabular}

LDL (Iow-density lipoproteins) - lipoproteiny o niskiej gęstości; HDL (high-density lipoproteins) lipoproteiny o wysokiej gęstości; ASpaT (aspartate aminotransferase) - aminotransferaza asparaginianowa; ALAT (alanine aminotransferase) - aminotransferaza alaninowa

dzinach porannych. W badaniach podstawowych (tab. 1) stwierdzono nieuzyskanie docelowych wartości cholesterolu frakcji LDL (low-density lipoprotien) (< $100 \mathrm{mg} / \mathrm{dl}$ według wytycznych Polskiego Towarzystwa Nadciśnienia Tętniczego [PTNT] z 2015 r.) oraz nieprawidłową glikemię na czczo. Na podstawie wytycznych z 2015 roku oszacowano ryzyko 
sercowo-naczyniowe jako wysokie. Zmodyfikowano leczenie hipotensyjne, włączając walsartan $160 \mathrm{mg}$ podawany wieczorem.

Ze względu na nieosiągnięcie docelowych wartości cholesterolu frakcji LDL zmodyfikowano również leczenie hipolipemizujące - simwastatynę zastąpiono rosuwastatyną w dawce $10 \mathrm{mg} /$ dobę. Ponownie zalecono wizytę kontrolną po 4 tygodniach od modyfikacji leczenia oraz wykonanie doustnego testu obciążenia 75 g glukozy.

Zalecone leczenie farmakologiczne obejmowało:

- indapamid w dawce $1,5 \mathrm{mg}(1 \times /$ d., rano);

- walsartan w dawce $160 \mathrm{mg}(1 \times / \mathrm{d}$., wieczorem);

- rosuwastatynę w dawce $10 \mathrm{mg}(1 \mathrm{x} / \mathrm{d}$., wieczorem).

Po 6 tygodniach średnia wartość ciśnienia tętniczego mierzonego przez chorą przez tydzień przed wizytą wynosiła 132/78 mm Hg - wartości zarówno w pomiarach porannych, jak i wieczornych były prawidłowe. W pomiarach klinicznych ciśnienie tętnicze wynosiło 134/79 mm Hg w pozycji siedzącej (średnia z 3 pomiarów). W kontrolnych badaniach nie stwierdzono istotnej zmiany stężeń potasu i kreatyniny. W doustnym teście obciążenia 75 g glukozy jej stężenie na czczo wynosiło $6,2 \mathrm{mmol} / \mathrm{l}$, a po 2 godzinach $8,5 \mathrm{mmol} / \mathrm{l}$. Chorej przypomniano o konieczności modyfikacji stylu życia oraz dołączono do leczenia metforminę w dawce 3 razy $500 \mathrm{mg}$.

Zalecono wizytę kontrolną za 3 miesiące. Ciśnienie tętnicze samodzielnie zmierzone przez pacjentkę wynosiło 128/76 mm Hg (średnia z tygodniowego okresu przed wizytą). W pomiarach klinicznych ciśnienie to wynosiło 133/78 mm Hg w pozycji siedzącej (średnia z 3 pomiarów). W badaniach biochemicznych stwierdzono uzyskanie docelowych wartości stężenia cholesterolu frakcji LDL; nie odnotowano istotnych zmian stężeń potasu i kreatyniny oraz aktywności kinazy fosfokreatyninowej i aminotransferazy alaninowej. W badaniu echokardiograficznym, poza istotnym koncentrycznym przerostem lewej komory, nie stwierdzono innych nieprawidłowości. Zalecono utrzymanie dotychczas stosowanego schematu leczenia; by je uprościć, przyjmowane dotychczas w postaci osobnych preparatów walsartan i rosuwastatynę zamieniono na preparat złożony (walsartan $160 \mathrm{mg}$ + rosuwastatyna $10 \mathrm{mg}$ ).

\section{Wnioski}

Przedstawiono przypadek 59-letniej kobiety z nadciśnieniem tętniczym współistniejącym z zaburzeniami gospodarki lipidowej oraz węglowodanowej, przerostem lewej komory i OSA. Zgodnie z wytycznymi PTNT z 2015 roku u chorej ryzyko sercowo-naczyniowe określono jako wysokie, co wskazuje na konieczność ścisłej kontroli wszystkich czynników ryzyka sercowo-naczyniowego [1]. U opisanej chorej zarówno w pomiarach domowych, jak i w ABPM stwierdzono nieprawidłową kontrolę ciśnienia tętniczego, przy granicznej kontroli ciśnienia w pomiarach gabinetowych. Wskazuje to na konieczność weryfikacji stopnia kontroli ciśnienia tętniczego o pomiary wykonywane poza gabinetem lekarskim. Podobnie jak w prezentowanym przypadku właściwie wykonywane pomiary domowe mogą być wykorzystywane przy podejmowaniu decyzji diagnostyczno-terapeutycznych podczas kolejnych wizyt lekarskich.

W wytycznych PTNT z 2015 roku wskazano na możliwość zastosowania leków hamujących układ renina-angiotensyna w chronoterapii nadciśnienia tętniczego (zastosowanie w godzinach wieczornych) u chorych obciążonych podwyższonym ciśnieniem tętniczym w nocy, brakiem obniżenia ciśnienia tętniczego w nocy czy nadmiernym porannym wzrostem ciśnienia [1]. Jednym z preparatów o udowodnionych w badaniach korzyściach z zastosowania w godzinach wieczornych jest walsartan [2, 3]. Zgodnie z zaleceniami PTNT z 2015 roku antagoniści receptora angiotensyny II należą do głównych grup leków stosowanych w terapii nadciśnienia tętniczego [1]. W prezentowanym przypadku stwierdzono zaburzenia metaboliczne i przerost lewej komory serca należące do sytuacji klinicznych przemawiających za zastosowaniem sartanu w terapii. W wytycznych PTNT z 2015 roku podkreślono, że optymalne zmniejszenie globalnego ryzyka powikłań sercowo-naczyniowych uzyskuje się poprzez jednoczesne obniżenie ciśnienia tętniczego i cholesterolu frakcji LDL [1]. Według wytycznych Europejskiego Towarzystwa Kardiologicznego (ESC, European Society of Cardiology) z 2016 roku i PTNT z 2015 roku w prezentowanym przypadku należało obniżyć stężenie cholesterolu LDL poniżej 100 mg/dl [1, 4]. Docelowe stężenie cholesterolu frakcji LDL uzyskano, stosując rosuwastatynę.

W aktualnych wytycznych wskazuje się na korzyści z zastosowania preparatów złożonych, przez co można uprościć schemat leczenia i poprawić stopień stosowania się do zaleceń przez chorych [1, 4]. Preparaty złożone, w których połączono lek hipotensyjny i statynę, dają nowe możliwości w zakresie terapii nadciśnienia tętniczego i zaburzeń lipidowych.

\section{Konflikt interesów}

Autorzy nie zgłaszają konfliktu interesów. 


\section{Abstract}

A case of 59-year-old woman with poorly controlled hypertension in the evening at night coexisting with dyslipidemia, impaired glucose tolerance, left ventricular hypertrophy and obstructive sleep apnea was reported. This case report presents the possibility of using ambulatory blood pressure measurements to optimize hypertensive therapy throughout the whole day. Current guidelines emphasize that optimal reduction in the global cardiovascular risk is achieved by simultaneous lowering of blood pressure and LDL (low-density lipoprotein) cholesterol. In this case, target blood pressure and target LDL cholesterol were obtained adding valsartan and rosuvastatin.

Key words: hypertension, dyslipidemia, chronotherapy of hypertension, cardiovascular risk

Folia Cardiologica 2017; 12, supl. B: B9-B12

\section{Piśmiennictwo}

1. Tykarski A, Narkiewicz K, Gaciong Z, et al. Zasady postępowania w nadciśnieniu tętniczym - 2015 rok. Wytyczne Polskiego Towarzystwa Nadciśnienia Tętniczego - wersja skrócona. Kardiol Pol. 2015; 73(8): 676700, doi: 10.5603/kp.2015.0157, indexed in Pubmed: 26304155.

2. Hermida RC, Calvo C, Ayala DE, et al. Administration time-dependent effects of valsartan on ambulatory blood pressure in hypertensive subjects. Hypertension. 2003; 42(3): 283-290, doi: 10.1161/01. HYP.0000084855.32823.DA, indexed in Pubmed: 12874091.
3. Hermida RC, Calvo C, Ayala DE, et al. Treatment of non-dipper hypertension with bedtime administration of valsartan. J Hypertens. 2005; 23(10): 1913-1922, indexed in Pubmed: 16148616.

4. Catapano AL, Graham I, De Backer G, et al. Authors/Task Force Members:, Authors/Task Force Members, Additional Contributor. 2016 ESC/EAS Guidelines for the Management of Dyslipidaemias. Eur Heart J. 2016; 37(39): 2999-3058, doi: 10.1093/eurheartj/ehw272, indexed in Pubmed: 27567407. 